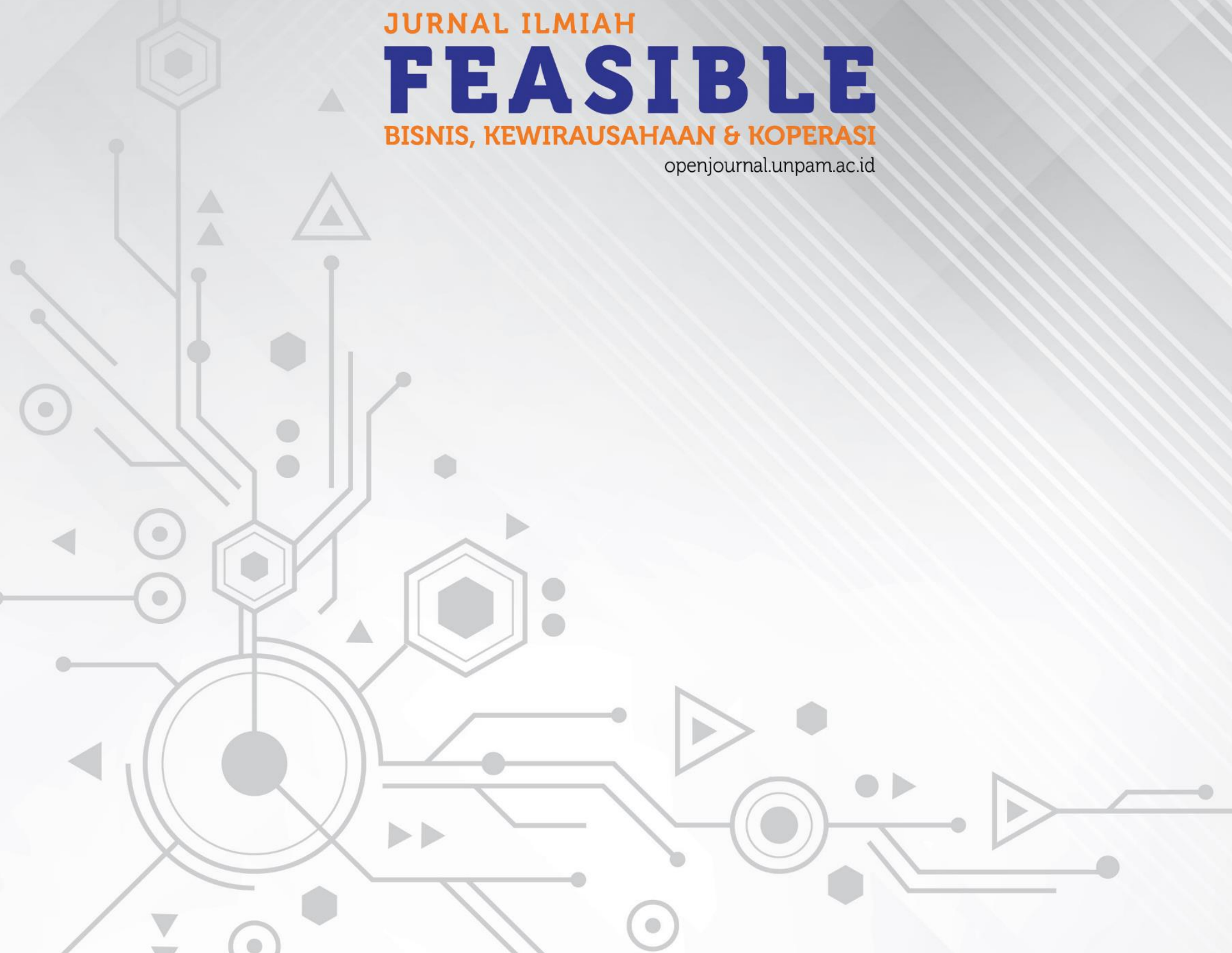




\title{
PERAN PASAR TRADISIONAL DAN PASAR KONTEMPORER SEBAGAI KARAKTERISTIK BANGSA DALAM MENINGKATKAN KESEJAHTERAAN MASYARAKAT DI LINGKUNGAN KOTA TANGERANG SELATAN
}

\author{
Sugeng Widodo'; Ferdina Watiningsih ${ }^{2}$ \\ Prodi Manajemen ; Universitas Pamulang \\ Dosen01632@unpam.ac.id
}

\begin{abstract}
Abstrak
Penelitian ini bertujuan untuk mengetahui keterlibatan masyarakat setempat terhadap keberadaan pasar tradisional yang seharusnya dapt dihandalkan sebagai tempat mencari penghasilan dan dapat meningkatkan tingkat ekonomi dan tingkat kesejatrhteraan masyarakat sekitar pasar. Metode penelitian mengunakan metode penelitian kualitatif, dengan populasi adalah masyarakat sekitar pasar tradisional, dengan responden sebanyak 8 orang, pengambilan data dilakukan dengan wawancara langsung dan observasi. Hasil Penelitian menggambarkan masyarakat sekitar pasar kurang mendapat keuntungan dari keberadaan pasar tradisioanal sehingga masyarakat mencari pekerjaan atau melakukan usaha di pasar tradisional tersebut. Adanya hubungnagn yang tidak baik antara masyarakat, pemerintah daerah dan pengelola pasar tradisiuonal sehingga sering terjadi konflik.
\end{abstract}

Kata Kunci: Pasar tradisional, Masyarakat, Kesejahteraan.

\begin{abstract}
This study aims to determine the involvement of local communities in the existence of traditional markets that should be relied upon as a place to look for income and can increase the level of the economy and the level of welfare of the community around the market. The research method uses qualitative research methods, with the population is the community around the traditional market, with 8 respondents, data collection is done by direct interviews and observations. The results of the study illustrate that communities around the market do not benefit from traditional markets so that people look for work or do business in these traditional markets. There is a bad relationship between the community, local government and traditional market managers, so that conflicts often occur.
\end{abstract}

Keywords: Traditional markets, Society, Welfare

\section{PENDAHULUAN}

Manusia telah mengenal dan melakukan kegiatan jual beli sejak mengenal peradaban sebagai bentuk pemenuhan kebutuhan. Dalam kegiatan jual beli, keberadaan pasar merupakan salah satu hal yang paling penting karena merupakan tempat untuk melakukan kegiatan tersebut selain menjadi salah satu indikator paling nyata kegiatan ekonomi masyarakat di suatu wilayah.

Bangsa Indonesia telah mengenal 
pasar khususnya pasar tradisional sejak lama. Berdasarkan Kamus Umum bahasa Indonesia pasar berarti tempat bertemunya penjual dan pembeli untuk melakukan suatu transaksi, dengankan tradisional dimaknai sikap dan cara berfikir serta bertindak yang selalu berpegang pada norma dan adat kebiasaan yang ada secara turun temurun. Berdasarkan arti tersebut, maka pasar tradisional adalah tempat orang berjual belu yang berlangsung di suatu tempat berdasarkan kebiasaan.

Di Indonesia keberadaan pasar tradisional bukan semata urusan ekonomi, tetapi lebih jauh kepada norma, ranah budaya, sekaligus peradaban yang berlangsung sejak lama di berbagai wilayah di Indonesia. Proses perekonomian masyarakat sebagian besar ditopang dalam sebuah proses jual beli dan hal ini terjadi dalam suatu pasar-pasar tradisional.

Pasar tradisional sering dianaktirikan masyarakat karena kondisinya yang tidak terjaga, suasana yang sumpek, kumuh, becek menjadi alasan yang membuat pasar tradisional sudah sedikit kurang diminati dibandingkan pasar modern yang cenderung lebih nyaman dalam melakukan transaksi.

Tabel 1.1. Data Penduduk

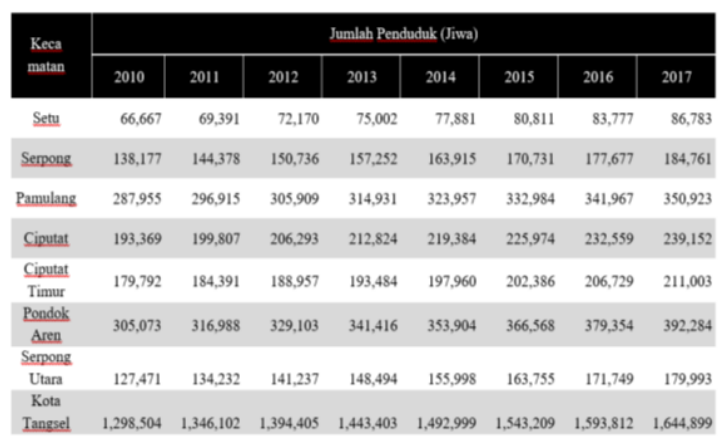

Karena proses perekonomian masyarakat sebagian besar ditopang dalam sebuah proses jual beli dan hal ini terjadi dalam suatu pasar baik pasar tradisonal khususnya pasar tradisional. Tentunya perbandingan ini dipengaruhi karena fasilitas pelayanan dan tempat lebih nyaman dan dijamin ketertibannya jika dibandingkan berbelanja di pasar tradisional yang cenderun panas, berdesakan dan tempat maupun lokasi yang kurang memadai. Di tengah arus modernisasi, keberadaan pasar tradisional sebagai suatu budaya bangsa saat ini mencoba untuk bertahan dan mengembangkan diri agar mampu bersaing ditengah arus tersebut. Liberalisasi investasi yang semakin tidak terbendung telah membuat pasar tradisional semakin terdesak dengan bermunculannya pasar modern yang menawarkan lebih banyak keunggulan komoditi, harga serta kenyamanan. Kenyataan tersebut telah membuat masyarakat Indonesia berpaling dari bagian kebudayaan dan beralih kepada kehidupan modern yang serba praktis dengan intensitas interaksi yang minim. Begitu pulagaya hidup yang juga mengalami perubahan yang sering mengikuti pola serba modern seperti pilihan makanan, cara berpakaian yang berakibat secara tidak langsung meninggalkan pasar tradisional yang merupakan asset ekonomi khusunya ekonomi daerah sekaligus perekat hubungan sosial dalam masyarakat dan 
kebudayaannya yang secara turun temurun.

Pembangunan pasar modern seperti minimarket dan pasar swalayan, yang memberikan fasilitas kenyamanan dalam diri masyarakat dapat berdampak negatif pula terhadap perekonomian masyarakat khususnya masyarakat ekonomi rendah yang mendapat penghidupan dari penjualan dari hasil dagangannya di pasar tradisional. Dalam menghadapi persaingan pasar-pasar modern sekarang ini setiap pasar tradisional dituntut untuk dapat bersaing dengan pasar-pasar modern yang berkembang bak jamur di musim hujan, pengaruh datangnya pasar modern terhadap pasar tradisional sangat kuat. Melihat begitu maraknya perkembangan pasar modern dengan beberapa kelebihan dalam pelayanan dan fasilitasnya, maka penulis ingin mengamati bagaimana pengaruh pasar tradisional sekarang ini sebagai karakteristik bangsa dalam meningkatkan kesejahteraan masyarakat di Lingkungan Kota Tangerang Selatan.

\section{Fokus Penelitian}

Dalam penelitian ini peneliti memfokuskan masalah terlebih dahulu supaya tidak terjadi perluasan permasalahan yang nantinya tidak sesuai dengan tujuan penelitian ini. Maka peneliti memfokuskan untuk meneliti apakah Pasar Tradisional sebagai karakteristik Bangsa dalam meningkatkan kesejahteraan masyarakat di Lingkungan Kota Tangerang Selatan dapat dirasakan Dengan mengetahui sikap masyarakat disekitar lingkungan keberadaan pasar tersebut. Sehingga dapat menjaga keberadaan pasar tradisional juga diharapkan dapat meningkatkan kembalinya orang-orang untuk tetap melakukan transaksi di Pasar Tradisional yang berdampak banyaknya mendapatkan kesejahteraan dari ramainya pasar tradisional.

\section{Rumusan Masalah}

1. Peningkatan Jumlah pasar ritel maupun pasar swalayan serta minimarket mempengaruhi keberadaan pasar tradisional sebagai karak teristik bangsa.

2. Kurangnya keterlibatan penduduk lokal sekitar pasar dan harus dilakukan peningkatan pelayanan pada suatu pasar tradisonal agar pengunjung pada pasar tradisional meningkat.

3. Bagaimana keberadaan pasar tradisional terhadap perekonomian masyarakat.

4. Dampak pembangunan pasar tradisional terhadap kesejahteraan masyarakat sekitar.

\section{Tujuan Penelitian}

Penelitian ini bertujuan untuk:

1. Menjelaskan pasar tradisional sebagai karakteristik bangsa

2. Menjelaskan keberadaan pasar tradisional sebagai sarana perekonomian terhadap masyarakat sekeliling.

3. Menjelaskan pasar tradisional dalam kaitannya dalam meningkatkan kesejahteraan masyarakat sekitar pasar 
tersebut.

\section{Kajian Literatur \\ Deskripsi Teori}

Menurut Peraturan Presiden RI

No. 112 Tahun 2007 tentang Penata-an dan Pembinaan Pasar Tradisional, Pusat Perbelanjaan, dan Toko Modern, "Pasar adalah area tempat jual beli barang dengan jumlah penjual lebih dari satu baik yang disebut sebagai pusat perbelanjaan, pasar tradisional, pertoko-an, mall, plaza, pusat perdagang-an maupun sebutan lainnya”. Stanton mengemukakan pengertian pasar yang lebih luas. "Pasar dikatakan merupakan orang-orang yang mempunyai keinginan untuk puas, uang untuk berbelanja dan kemauan untuk membelanjakannya. Jadi dalam pengertian tersebut terdapat fakor-faktor yang menunjang terjadinya pasar, yakni : keinginan, daya beli dan tingkah laku dalam pembelian".

Sedangkan menurut Peraturan Daerah Kota Tangerang Selatan No. 15 Tahun 2011, yang dimaksud dengan "pasar adalah area tempat jual beli barang dengan jumlah penjual lebih dari satu baik yang disebut sebagai pusat perbelanjaan, pasar tradisional, pertokoan, mall, plasa, pusat perdagangan maupun sebutan lainnya”.

\section{Jenis Pasar}

1. Pasar Tradisional

"Pasar Tradisional adalah pasar yang dibangun dan dikelola oleh pemerintah, swasta, koperasi atau swadaya masyarakat dengan tempat usaha berupa toko, kios, los dan tenda yang dimiliki atau dikelola oleh pedagang kecil dan menengah, dan koperasi dengan usaha skala kecil, modal kecil dan dengan proses jual beli melalui tawar menawar". Pasar tradisional lebih terarah kepada semua lapisan masyarakat walaupun lebih khususnya kepada masyarakat lapisan menengah dan bawah. Ditambah lagi dengan berlakunya sistem tawar menawar yang membuat masyarakat merasa lebih mudah dalam membeli dan memenuhi kebutuhannya karena bisa lebih menyesuaikan dengan uang juga daya beli yang dimilikinya.

Pasar tradisional ini umumnya terletak dekat kawasan pemukiman agar memudahkan pembeli untuk mencapai pasar. Pasar tradisional bukan hanya tempat bertemunya penjual dan pembeli tetapi juga sebagai penggerak perekonomian masyarakat. Tidak sedikit masyarakat kecil yang menggantungkan hidupnya dengan cara berjualan di pasar tradisional tersebut guna memenuhi kebutuhan hidupnya. Dalam pasar tradisional terdapat ciri khusus yang bisa menggambarkan pasar tradisional tersebut, secara umum ciri pasar tradisional adalah tidak adanya sistem/manajemen dalam proses penjualan dan biasanya identik dengan tempat yang bau, kumuh, becek dan kotor dan ciri yang paling melekat 
adalah terdapatnya system tawar menawar harga untuk setiap barang yang diperjual belikan.

2. Pasar Modern

Pasar modern adalah pasar yang dibangun oleh pemerintah, swasta atau koperasi yang bentuknya berupa mall, supermarket, departemen store dan shopping center dimana pengelolaannya dilaksanakan secara modern, mengutamakan pelayanan dan kenyamanan berbelanja dengan dilengkapi label harga yang pasti dan tidak terjadinya tawar menawar. Sehingga cara bertansaksi antar penjual dan pembeli terjadi secara tidak langsung, pembeli melihat harga pada label harga dan mengambil barang yang mau dibelinya sendiri yang kemudian dibayarkan ke kasir.

\section{Karakteristik Bangsa}

Secara psikologi konsep dari karakter bangsa adalah konsep individual. Jika kemudian hal tersebut menjadi suatu karakter bangsa maka perlu adanya acuan. Artinya, dari konsep individual menjadi sebuah konsep kemasyarakatan dan lebih luas lagi bagi bangsa, maka haruslah ada instrument sebagai alat evaluasi yaitu kebudayaan. Secara ringkas kebudayaan berisi system nilai, norma dan kepercayaan mereka. Dengan demikian dalam konteks ini budaya dapat dianggap sebagai instrument untuk melihat kecenderungan perilaku pengembangnya.
Karakteristik bangsa Indonesia bersifat dinamis, dapat berubah dari suatu periode waktu tertentu ke periode lainnya, walaupun tidak mudah. Sebagai contoh adalah Indonesia sering dikatakan sebagai bangsa timur bangsa yang mempunyai karakter sopan, santun, ramah tamah, berperasaan halus dan lainnya yang menggambarkan sebuah sikap atau perilaku yang mengindikasikan keluhuran budi pekerti.

\section{Kesejahteraan}

Merujuk pada undang-undang No. 11 tahun 2009 yang dikutip oleh Suharto (2009:153) mendefinisikan"Kesejahteraan adalah kondisi terpenuhinya kebutuhan material, spiritual dan sosial Warga Negara agar dapat hidup layak dan mampu mengembangkan diri , sehingga dapat melakukan fungsi sosialnya".

Adanya pemenuhan kebutuhan oleh masyarakat baik itu materil, spiritual dan sosial sehingga akan mendorong masyarakat menuju kearah kualitas hidup yang lebih baik dan mencapai fungsi sosialnya. Menurut Fahrudin (2012:10) Kesejahteraan mempunyai tujuan yaitu: "(1) Untuk mencapai kehidupan yang sejahtera dalam arti tercapainya standar kehidupan pokok seperti sandang, perumahan, pangan, kesehatan, dan relasirelasi sosial yang harmonis dengan lingkungannya; (2) Untuk mencapai penyesuaian diri yang baik khususnya dengan masyarakat di lingkungannya, misalnya dengan menggali sumber- 
sumber, meningkatkan, dan mengembangkan taraf hidup yang memuaskan.

\section{Kerangka Berpikir}

Kerangka pemikiran merupakan miniatur keseluruhan dari proses penelitian. Kerangka pemikiran harus menerangkan, mengapa penelitian dilakukan, bagaimana proses penelitian dilakukan, apa yang akan diperoleh dari penelitian tersebut dan untuk apa hasil penelitian diperoleh

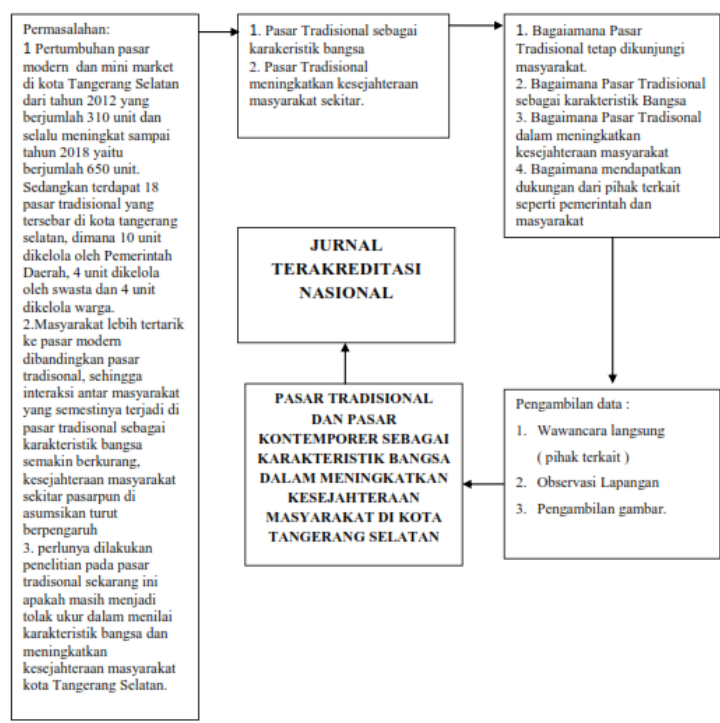

Gambar 1.1. Kerangka Berfikir Penelitian

\section{METODE}

\section{Jenis Penelitian}

Jenis penelitian ini adalah penelitian kualitatif deskriptif, yaitu data yang dikumpulkan berbentuk kata-kata, gambar, bukan angka-angka. Menurut Bogdan dan Taylor, sebagaimana yang dikutip oleh Lexy J. Moleong, "penelitian kualitatif adalah prosedur penelitian yang menghasilkan data deskriptif berupa katakata tertulis atau lisan dari orang-orang dan perilaku yang diamati”. Sementara itu, "penelitian deskriptif adalah suatu bentuk penelitian yang ditujukan untuk mendeskripsikan atau menggambarkan fenomena -fenomena yang ada, baik fenomena alamiah maupun rekayasa manusia”.

\section{Tempat dan Waktu Penelitian}

Lokasi penelitian terletak di 8 unit Pasar yang dikelola oleh Pemerintah Daerah Tangerang Selatan yaitu: Pasar Ciputat, Pasar Jombang, Pasar Kita, Pasar Jengkol, Pasar Cimanggis, Pasar Bintaro Sektor 2, Pasar Gintung dan Pasar Serpong. Penelitian ini dilakukan pada wilayah kota Tangerang selatan yang merupakan salah satu kota di propinsi Banten. Lokasi Kota Tangerang pada bulan April sampai Agustus 2019.

\section{Sumber Data}

Menurut Lofland dan Loflan sebagaimana telah dikutip oleh Lexy.J. Moleong dalam bukunya mengemukakan bahwa sumber data utama dalam penelitian kualitatif adalah kata-kata dan tindakan, selebihnya berupa data tambahan seperti dokumen dan lain-lain. Berkaitan dengan hal itu pada bagian ini jelas datanya dibagi ke dalam kata-kata dan tindakan, sumber data tertulis, foto dan statistik. Dalam penelitian ini sumber data primer berupa kata-kata diperoleh dari wawancara dengan para informan yang telah ditentukan yang meliputi berbagai hal yang berkaitan dengan peran pasar tradisional dan pasar kontemporer sebagai karakteristik bangsa dalam meningkatkan 
kesejahteraan masyarakat di Kota Tangerang Selatan. Sedangkan sumber data sekunder dalam penelitian ini berupa data statistik pasar, serta dokumentasi kegiatan dalam pasar tersebut.

\section{Teknik Pengumpulan Data}

Menurut Arkunto (2002), “Teknik pengumpulan adalah cara-cara yang dapat digunakan oleh peneliti untuk mengumpulkan data, di mana cara tersebut menunjukkan pada suatu yang abstak, tidak dapat di wujudkan dalam benda yang kasat mata, tetapi dapat di pertontonkan penggunaannya”. Pengumpulan data diperoleh melalui observasi, wawancar/ interview dan dokumentasi.

\section{Uji Keabsahan Data}

Keabsahan data dalam penelitian ini ditentukan dengan menggunakan kriteria kredibilitas. Untuk mendapatkan data yang relevan, maka peneliti melakukan pengecekan keabsahan data hasil penelitian dengan cara: perpanjangan pengamatan, ketekunan pengamatan, dan triangulasi (pengecekan data dari berbagai sumber)

\section{Teknik Analisis Data}

Analisis data yang digunakan adalah metode deskriptif analitik, yaitu mendeskripsikan data yang dikumpulkan berupa kata-kata, gambar, dan bukan angka. Data yang berasal dari naskah, wawancara, catatan lapangan, dokumen dan sebagainya, kemudian dideskripsikan sehingga dapat memberikan kejelasan terhadap kenyataan atau realitas. Teknik anlisa data yang digunakan meliputi: 1) reduksi data yaitu proses pemilihan pemusatan perhatian pada penyederhanaan, pengabstrakan dan transformasi data-kasar yang muncul dari catatan lapangan; 2) Penyajian data yaitu pendeskripsian sekumpulan informasi tersusun yang memberikan kemungkinan adanya penarikan kesimpulam dan pengambilan tindakan; dan 3) Penarikan kesimpulan atau verifikasi merupakan kegiatan akhir penelitian kualitatif.

\section{Road Map Penelitian}

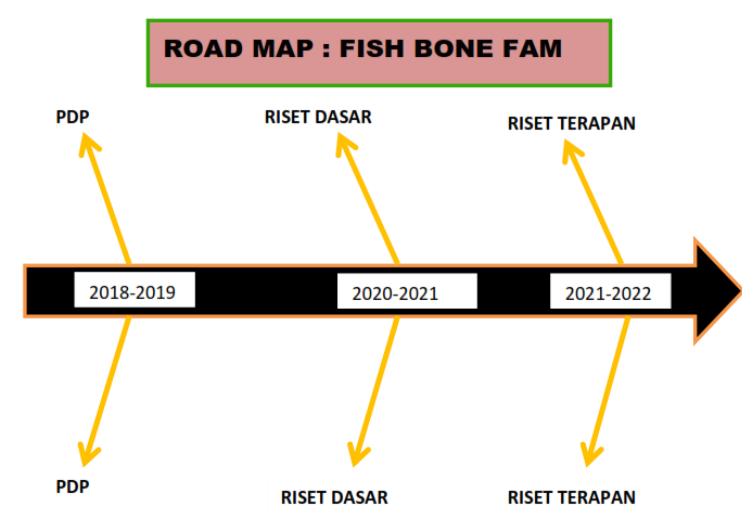

Gambar 1.2. Road Map Penelitian

Keterangan :

1. Penelitian Dasar penerimaan dana hibah Dikti PDP 2018/2019 dengan judul : "Peran Pasar Tradisional Dan Pasar Kontemporer Sebagai Karakteristik Bangsa Dalam Meningkatkan Kesejahteraan Masyarakat Di Lingkungan Kota Tangerang Selatan”.

2. Rencana penelitian Riset dasar dengan membuat penelitian berkenaan pada kesejahteraan Pedagang pengajuan kompetisi Nasional penelitian dasar tahun 2020-2021. 
3. Rencana penelitian Riset Terapan setelah hasil penelitian dasar yang di dapat di lapangan sehingga memerlukan terapan kebijakaan kesejahteraan Lingkungan masyarakat Pedagang sekeliling pasar.

\section{HASIL dan \\ PEMBAHASAN}

Tangerang selatan adalah salah satu kota di Provinsi Banten, Indonesia. Kota ini diresmikan pada tanggal 29 Oktober 2008. Kota Tangerang selatan adalah merupakan pemekaran dari Kabupaten Tangerang. Pada masa penjajahan Belanda, wilayah ini masuk ke dalam keresidenan Batavia dan mempertahankan karakteristik tiga etnis, yaitu suku sunda, suku betawi dan Tionghoa. Pembentukan wilayah ini sebagai kota otonom berawal dari keinginan warga di kawasan Tangerang Selatan untuk mensejahterakan masyarakat karena warga wilayah Tangerang Selatan ini merasa kurang diperhatikan Pemerintah Tangerang sehingga banyak fasilitas terabaikan. Hingga DPRD kabupaten Tangerang menyetujui terbentuknya Tangerang Selatan. Kota Tangerang Selatan ini terdiri atas tujuh kecamatan, yakni, Ciputat, Ciputat Timur, Pamulang, Pondok Aren, Serpong, Serpong Utara dan Setu.

Salah satu fasilitas Kota Tangerang Selatan adalah Pasar Tradisional, karena masih dalam proses pemekaran, setiap kecamatan belum mewakili memiliki pasar sendiri, berikut adalah pasar yang berada dalam wilayah kota Tangerang Selatan

\section{Hasil Observasi dan wawancara langsung}

\section{a. Bapak Agus salim (52 th) : Ketua RT o1/RW o3, Pasar Kita.}

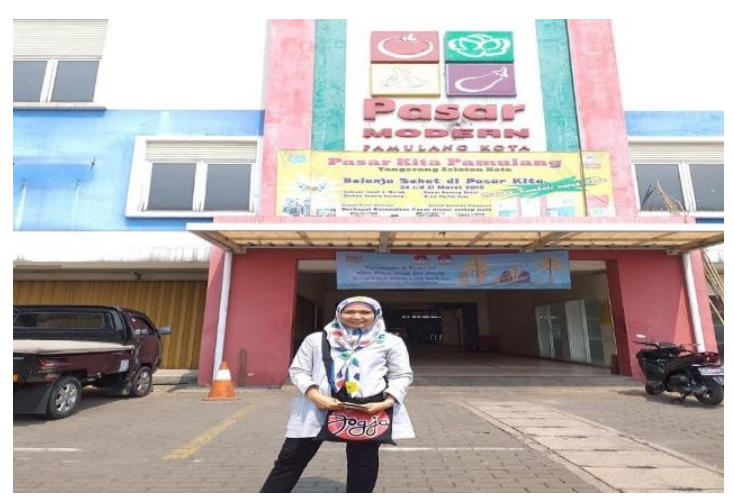

Keberadaan Pasar Kita) di kelurahan Pamulang Barat kecamatan Pamulang Kota Tangerang Selatan, secara tidak langsung memberikan kesejahteraan bagi warga yang tinggal sekitar pasar kita Pamulang tersebut. Situasi pasar kita secara umum tidak seramai pasar tradisional lainnya. Masyarakat disekitar pasar lebih memilih bekerja di tempat yang jauh. Dengan biaya sewa yang tidak terjangkau masyarakat sekitar, sehingga masyarakat sekitar tidak memiliki kemampuan untuk berjualan di dalam pasar kita.

\section{b. Bapak Suryadi Jaya (62 th): Ketua RT oo3, Pasar Ciputat}

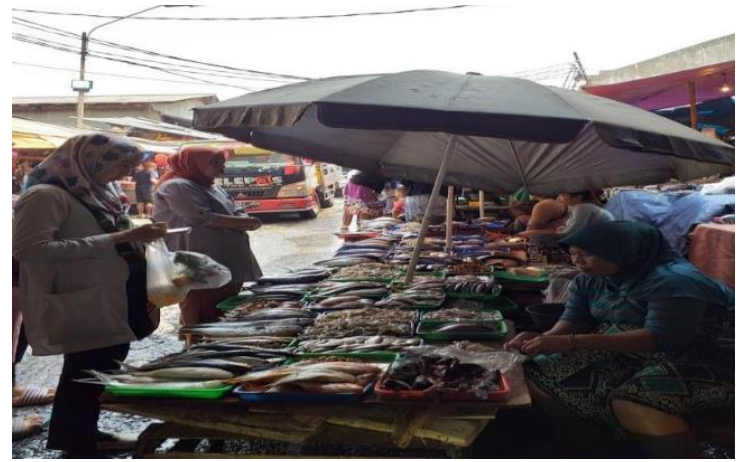

Kondis pasar Ciputat menurutnya 
selalu ramai, sehingga berdampak kepada kemacetan lalu lintas di sekitar pasar. Selain itu di sekitar pasar juga ada mall ciputat. Keberadaan pasar sangat mengangkat kondisi perekonomian dan kesejahteraan masyarakat sekitar. Karena masyarakat di sekitar pasar dapat mendirikan kioas/took/warung di sekitar jalan menuju pasar. Sebagian besar masyarakat asli bekerja di luar pasar Ciputat.

\section{c. Bapak H. Hisbulah (65 th) : Rt o4, Pasar Jombang}

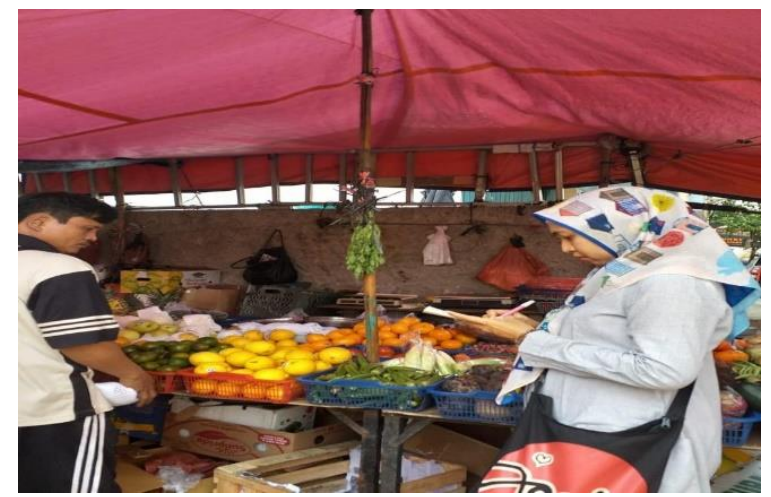

Jumlah pedagang yang dapat di data di Pasar Jombang mencapai 386 pedagang, sedangkan pedagang pinggiran yang tidak terdata bisa mencapai +300 pedagang, Sebagian besar pedagang di Pasar Jimbang adalah pendatang yang berasal dari Jawa, Kuningan, Medan dan Sunda.Untuk pedagang dari warga sekitar 10 orang pedagang saja. Sebagian besar warga sekitar pasar bekerja di luar, ada juga yang bekerja di pasar sebagai juru parkir dan keamanan pasar.

\section{d. Bapak Setio Budi : Rt o3, Pasar Arinda.}

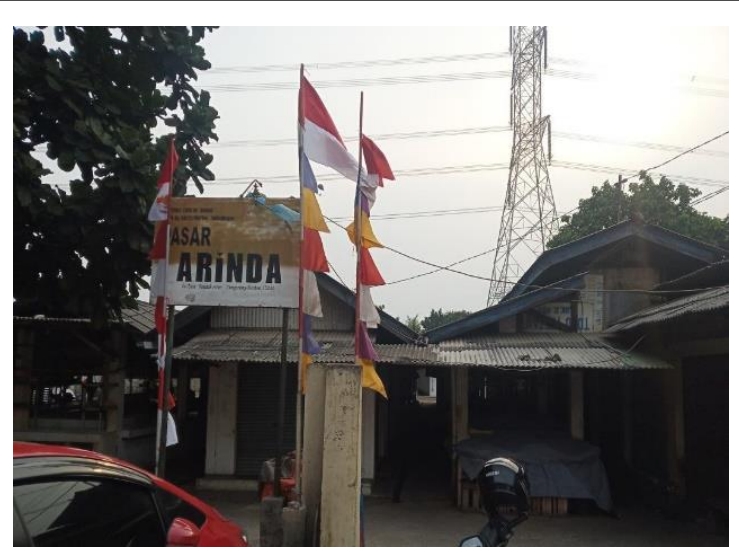

Dari jumlah penduduk sekitar pasar yang berjumlah 450 orang, yang berdagang di Pasar Arinda berjumlah \pm 10 orang dari 102 pedagang. Hampir $90 \%$ orang luar yang memanfaatkan untung mencari ekonomi dagang diwilayahnya, para pedagang adalah pendatang diluar wilayah RT 03. Sedangkan warga sekitar pasar lebih banyak yang bekerja diluar. Ini menjadikan kurangnya daya tarik warga terhadap keberdayaan pasar. Yang seharusnya mampu menyuguhkan perekonomian juga kesejahteraan dengan adanya pusat ekonomi masyarakat seharusnya. Jelas ini perlu adanya kebijakan dari pemerintah daerah tentang penataan pasar agar tercipta pasar yang baik dan mampu memberikan dukungan ekonomi masyarakat sekitar pasar khusus penduduk asli, sehingga tidak perlu jauh-jauh bekerja mencari ekonomi. Jika dilingkungan pasar sudah 
memadai dan cukup.

\section{e. Bapak Mansur : Ketua Rw o8/o2 Pasar Ceger}

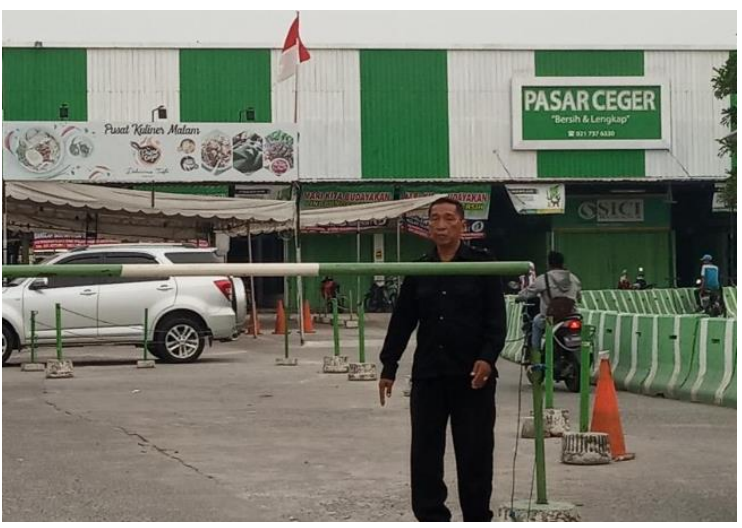

Menurut pak mansur dari jumlah pedagang, kecamatan pondok aren. Dengan jumlah kios \pm 250 banyak diisi orang pendatang, sedangkan warga sekitar kurang tertarik, lebih banyak kerja diluar. Ini sangat disayangkan sekali dimana penduduk asli /lokal banyak yang memilih bekerja diluar wilayahnya dikarenakan tidak punya tempat untuk usaha/berdagang dikarenakan sewa tempat atau kios yang mahal. Juga karena tidak adanya modal untuk berdagang. Jadi untuk membiayai hidup keluarganya banyak warga disekeliling pasar ceger bekerja diluar, menjadi buruh bangunan, ojek online, tenaga administrasi. Kalaupun ada yang aktif atau aktifitas hanya menjadi juru parkir dan tenaga keamanan dipasar ceger.

\section{f. Ibu laila : Pengelola Pasar Bintaro sektor 2.}

Menurut ibu sebagai pengelola pasar Bintaro sektor 2. Untuk jumlah pendagang yang \pm 135 banyak diisi oleh warga pendatang, dimana warga pendatang yang ulet dan rajin. Sedangkan untuk warga asli bisa dihitung. Ini menandakan masih kurangnya warga yang interaksi. memanfaatkan keberadaan pasar di wilayahnya. Sangat disayangkan sekali

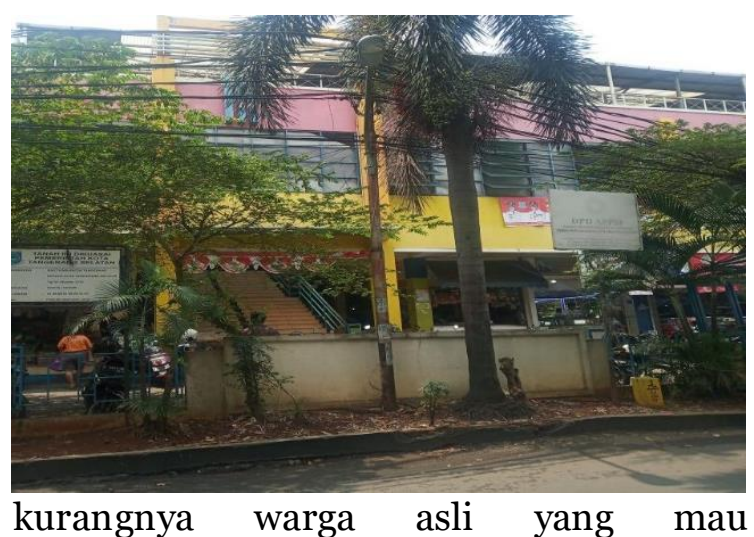
bermaksimal memanfaatkan wilayahnya sebagai pusat ekonomi dengan keberadaan pasar tradisional ini, dimana seharusnya mampu dan bisa meningkatkan ekonomi dari pada harus bekerja jauh-jauh dari tempat tinggalnya.

\section{g. Ibu Sri : Pasar Modern Bintaro Jaya.}

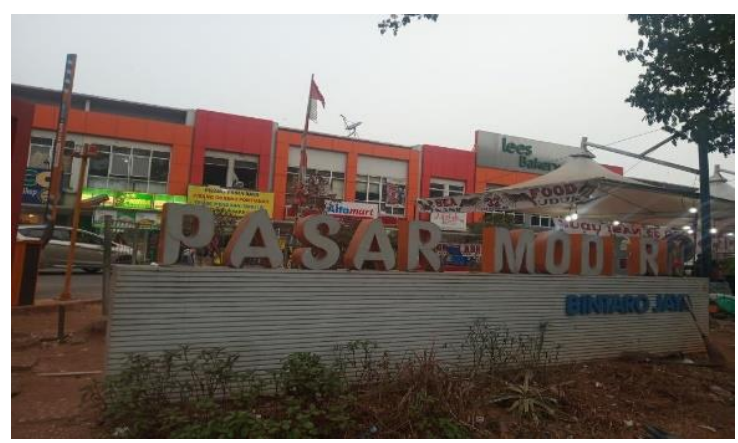

Menurut ibu Sri untuk jumlah pedagang di pasar modern bintaro yang jumlahnya mencapai 200 , alamat dijalan tegal rotan raya no. 2. Warga yang ikut berdagang tidak banyak bisa di hitung justru warga pendatang yang banyak mengisi kios dan los usaha. Tapi untuk tenaga parkir dan keamanan ada penduduk lokal atau sekeliling pasar modern bintaro 
jaya yang menjadi karyawan. Padahal jikan masyarakat skitar mau ulet dan berusaha disini akan lebih baik karena tidak usah jauh-jauh bekerja mencari ekonomi ketempat lain. Tapi ini juga perlu kesadaran masyarakat sekiling yang merasa menjadi bagian dari keberadaan pasar modren bintaro jaya. Dimana saat ini pasar bintaro jaya sudah sangat berkembang bisa dibilang modern dibanding sebelum dibangun. Dimana bisa dilihat sudah tertata dan bersih.

\section{h. Bapak Husin : Rt o2/o8, pasar Serpong.}

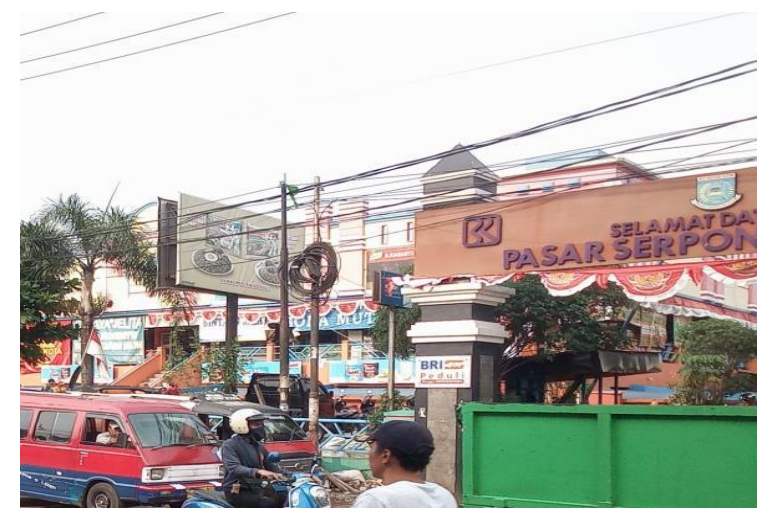

Menurut bapak husin, dari jumlah pedagang \pm 837 baik kios, los. Sesungguhnya jumlah pedagang yang jika dilihat yang real melebihi dari angka 837, karena ada pedangan kaki lima, yang belum terdata sedangkan kios \pm 1.500. Ini ada hanya sekitar $\pm 5 \%$ yang bisa memanfaatkan keberadaan pasar sebagai pusat ekonomi masyarakat sekitar. Tapi belum juga bisa dirasakan adanya manfaat yang signifikan untuk kesejahteraan masyarakat. Justru warga sekiling banyak yang bekerja diluar sekitar pasar. Jika ada yang dipasar juga hanya sebagai tenaga keamanan dan juru parkir. Bagaimana ini juga menurut bapak husin sangat disayangkan banyak masyarakat asli yang masih kurang ikut memanfaatkan fasilitas pasar yang ada. Padahal ini bisa menjadi sarana mencari sumber ekonomi keluarga daripada harus bekerja di tempat yang jauh dari tempat tinggal.

\section{SIMPULAN}

\section{Kesimpulan}

Berdasarkan hasil penelitian yang telah kami laksanakan dengan mengadakan kunjungan langsung kepasar dan lingkungan serta observasi dilapangan. Maka kesimpulan yang dapat kami berikan :

1. Penduduk lokal yang memang tinggal di lingkungan kurang merasa memiliki keberadaan pasar dimana sebagai penunjang ekonomi.

2. Keberadaan pasar tradisional disekitar lingkungan tinggal penduduk lebih banyak diisi oleh pendatang yang melihat kesempatan dalam mendapatkan rezeki/ perekonomiannya.

3. Koordinasi antara pejabat lingkungan dengan masyarakat tentang keberadaan pusat ekonomi (pasar) yang dapat menjadi andalan kurang pendapatan warga lokal kurang mendapat penjelasan yang memotivasi.

4. Perlu adanya kesadaran gerakan cinta akan pasar tradisional bagi masyarakat lokal agar dapat menjadikan sumber pendapatannya dengan ikut terjun langsung yang dibantu oleh pengurus setempat pengelola pasar dan pejabat 
lingkungan yang memberikan fasilitas.

\section{Saran}

Saran yang dapat kami berikan untuk keberlangsungan dan kelancaran masyarakat lokal ikut kontribusi ;

1. Adanya pendekatan kembali antara pengurus/pengelola pasar dengan memberikan pentingnya pusat ekonomi yang dekat dengan lingkungan sebagai sarana mendapatkan penghasilan dari pada bekerja di tempat yang jauh.

2. Adanya koordinasi anatara pejabat lingkungan dan pengelola pasar tradisional untuk meningkatkan prasarana yang baik dan mengunakan pasar sebagai sarana silaturahim antar warga juga dapat ekonomi kehidupan.

3. Adanya peraturan yang baik dalam jangka panjang dalam mengelola keamanan, kebersihan, ketertiban pasar tradisional sebagai warisan bangsa yang penuh dengan proses saling sapa dan transaksi yang baik.

\section{DAFTAR PUSTAKA}

Anderson, James E. 1984. Public PolicyMaking. New York: Holt, Rinehart and Winston.

Awang, Azam. 2010. Implementasi Pemberdayaan Pemerintah Desa. Yogyakarta: Pustaka Pelajar.

Badan Pusat Statistik (BPS) Kota Tangerang Selatan, Kota Tangerang Selatan Dalam Angka, 2017
Bardach, Eugene. 1977. The Implementation Game. Cambridge, Mass: Mitt Press.

Chourmain, Imam, dan Prihatin. 1994. Pengantar Ilmu Ekonomi. Jakarta: Departemen Pendidikan dan Kebudayaan.

Kumorotomo, Wahyudi. 2013. Etika Administrasi Negara. Jakarta: PT Raja Grafindo Persada.

Lexy.J. Moleong, 2017 Metdologi Penelitian Kualitatif, Bandung

Nazir, Moh, Ph.D. 2017. Metodologi Penelitian. Ghalia Indonesia.Bogor

Nugroho, Riant. 2008. Public Policy. Jakarta: PT Elex Media Komputindo.

Suharsimi, Arikunto, 2002. Prosedur Penelitian Suatu Pendekatan Praktek, PT Rineka Cipta, Jakarta

Sugiyono. 2017. Metode Penelitian Kuantitatif, Kualitatif, dan R\&D. Alfabeta. Bandung

Sutedi, Adrian. 2011. Hukum Perizinan dalam Sektor Pelayanan Publik. Jakarta: Sinar Grafika.

Keputusan Menteri Perindustrian dan Perdagangan Republik Indonesia No. 420/MPP/Kep/10/1997

Keputusan Menteri Perindustrian dan Perdagangan RI Nomor 107/MPP/ Kep/2/1998 tentang Ketentuan dan Tata Cara Pemberian Izin Usaha Pasar Modern

Peraturan Presiden RI No. 112 Tahun 2007 tentang Penataan dan Pembinaan Pasar 
Tradisional, Pusat Perbelanjaan dan Toko Modern. 231

Peraturan Menteri Perdagangan RI No. 53 Tahun 2008 tentang Pedoman Penataan dan Pembinaan Pasar Tradisional, Pusat Perbelanjaan, dan Toko Modern.

Peraturan Menteri Perdagangan RI Nomor 68/M-DAG/PER/10/2012 tentang Waralaba untuk Jenis Usaha Toko Modern.

Peraturan Menteri Perdagangan RI Nomor 70/M-DAG/PER/12/2013 tentang Pedoman Penataan dan Pembinaan asar Tradisional, Pusat Perbelanjaan, dan Toko Modern.

Website : Hadi, Ilman. 2012. Ketentuan tentang Jarak Minimarket dari Pasar Tradisiona9l. http://www.m. hukumonline.com. Diakses pada tanggal 18 Maret 2019.

Subekti, Nanang. 2007. Menteri Perindustrian. http://www.portal. mahkamahkonstitusi.go.id. Diakses pada tanggal 18 Maret 2019.

—. 2013. Peraturan Pemerintah (Indonesia).http://id.wikipedia. 